Mystic Union 
Cornell Studies in the Philosophy of Religion

EDITED BY WILLIAM P. ALSTON

God, Time, and Knowledge

by William Hasker

On a Complex Theory of a Simple God: An Investigation in Aquinas'

Philosophical Theology

by Christopher Hughes

Time and Eternity

by Brian Leftow

Rationality and Theistic Belief: An Essay on Reformed Epistemology by Mark S. McLcod

Theology in the Age of Scientific Reasoning

by Nanccy Murphy

Mystic Union: An Essay in the Phenomenology of Mysticism by Nclson Pikc

Divine Hiddenness and Human Reason

by J. L. Schellenberg

The Nature of God: An Inquiry into Divine Attributes

by Edward R. Wierenga 


\section{Nelson Pike}

\section{Mystic Union \\ An Essay in the}

Phenomenology of Mysticism

Cornell University Press, Ithaca and London 
Copyright (C) 1992 by Corncll University

All rights reserved. Except for bricf quotations in a review, this book, or parts thereof, must not be reproduced in any form without permission in writing from the publisher. For information, address Corncll University Press, Sage House, 5I 2 East State Strect, Ithaca, New York I48 so.

First published I 992 by Cornell University Press. First printing, Cornell Paperbacks, I994.

\section{Library of Congress Cataloging-in-Publication Data}

Pike, Nelson.

Mystic union : an essay in the phenomenology of mysticism / Nelson Pike.

p. $\mathrm{cm}$. - (Cornell studies in the philosophy of religion)

Includes bibliographical references and index.

ISBN o-80 I 4-2684-7 (alk. paper). - ISBN o-8014-9969-o (pbk. : alk. paper) I. Mystical union. I. Title. II. Series.

BT767.7.P55 1992

$248.2^{\prime} 2-\mathrm{dc} 20$

$9 I-55553$

Printed in the United States of America

The paper in this book meets the minimum requirements of the American National Standard for Information Sciences-Permanence of Paper for Printed Library Materials, ANSI Z 39.48-I984. 
To my two sons,

Kevin Allen and

Joel Raymond 
